\title{
Development of a New Predictive index (Bathing Water Quality Index, BWQI) Based on Escherichia coli Physiological States for Bathing Waters Monitoring
}

\author{
Simone Bonamano ${ }^{1,2} \oplus$, Alice Madonia ${ }^{1,2}$, Gabriella Caruso ${ }^{3, *}\left(\mathbb{C}\right.$, Giuseppe Zappalà ${ }^{4}$ and Marco Marcelli ${ }^{1,2}$ \\ 1 Laboratory of Experimental Oceanology and Marine Ecology (DEB), Tuscia University, \\ 00053 Civitavecchia, Italy; simo_bonamano@unitus.it (S.B.); alice_madonia@unitus.it (A.M.); \\ marcomarcell@unitus.it (M.M.) \\ 2 Fondazione Centro Euro-Mediterraneo sui Cambiamenti Climatici (CMCC), 73100 Lecce, Italy \\ 3 Institute of Polar Sciences (ISP), National Research Council (CNR), 98122 Messina, Italy \\ 4 Institute of Biological Resources and Marine Biotechnologies (IRBIM) National Research Council (CNR), \\ 98122 Messina, Italy; giuseppe.zappala@cnr.it \\ * Correspondence: gabriella.caruso@cnr.it; Tel.: +39-090-6015423
}

check for updates

Citation: Bonamano, S.; Madonia, A.; Caruso, G.; Zappalà, G.; Marcelli, M. Development of a New Predictive index (Bathing Water Quality Index, BWQI) Based on Escherichia coli Physiological States for Bathing Waters Monitoring. J. Mar. Sci. Eng. 2021, 9, 120. https://doi.org/ $10.3390 /$ jmse 9020120

Academic Editors: Michele Arienzo and Casotti Raffaella

Received: 23 December 2020

Accepted: 20 January 2021

Published: 26 January 2021

Publisher's Note: MDPI stays neutral with regard to jurisdictional claims in published maps and institutional affiliations.

Copyright: (c) 2021 by the authors. Licensee MDPI, Basel, Switzerland. This article is an open access article distributed under the terms and conditions of the Creative Commons Attribution (CC BY) license (https:// creativecommons.org/licenses/by/ $4.0 /)$.
Abstract: Bacterial pathogens in coastal aquatic ecosystems pose a potential public health hazard for bathing water use. The European Bathing Water Directive (2006/7/EC) currently relies on the culturability of fecal pollution bacterial indicators such as Escherichia coli, without considering dormant or quiescent (Viable But Not Culturable, VBNC) cells, whose possible resuscitation after bathers ingestion cannot be excluded. Standard methods are also time-consuming and therefore hardly meet early warning needs of marine monitoring. To solve this issue, a new index, the Bathing Water Quality Index (BWQI), has here been developed, allowing to identify the most favorable coastal zones for recreational use. The index was calculated by combining numerical simulations of living and dormant E. coli abundances and their residence times. To specifically set up the model with the different physiological states of the whole E. coli population, an ad hoc experiment based on the fluorescent antibody method was performed. The BWQI application to Santa Marinella bathing area highlights a potential risk for human health in the zone most frequented by bathers. This study provides a predictive tool to support preventive decisions of the competent authorities and to properly protect bathers' health, stressing the need for improved methods for environmental monitoring.

Keywords: bathing waters; Escherichia coli; bacterial physiological states; mathematical models; monitoring

\section{Introduction}

Coastal areas are undoubtedly the most vulnerable areas of the marine environment, being characterized by a large number of anthropic activities (industries, businesses, tourism, etc.) as well as high human impact. The multiple pressures exerted from increasing urbanization, marine/maritime activities, besides climate change, affect the status of Mediterranean ecosystems. Recent initiatives such as BlueMed in its Implementation Plan and the Ocean decade Workshop "The Mediterranean Sea we need for the future we want" have stressed the importance of addressing these trends, through development of effective monitoring and robust predictions of the coastal areas, that are crucial to support efforts for sustainable development and resilience of societies and ecosystems. Coastal Mediterranean environments are highly susceptible to pollution, in relation to their multipleuses and the impacts they are exposedto.Economical and productive settlements, industries and power plants, marinas and commercial ports involve the presence of numerous sources that spill into the sea abundant volumes of polluted waters. Increase of population density, such as during summer, or intense meteo-climatic phenomena, may determine significant increments in the volume of wastewater transported by sewerage pipelines, that overflow, 
discharging directly into the sea, without any preliminary depuration treatment, so potentially conveying high concentrations of pathogenic microorganisms. Currently, however, the risk to human health in coastal bathing areas is assessed by taking into account the abundance of Escherichia coli cells that can be retrieved on culture media only. However, several studies (see the review by Pinto et al. [1]) have recently documented the occurrence in coastal marine waters of dormant or viable but not culturable (VBNC) bacterial cells, that are not detectable through conventional culture methods. The abundance and culturability of human enteric pathogens are affected by several physical and chemical drivers [2]. Dormancy is considered as a survival strategy adopted by bacteria to overcome environmental stressing conditions such as extreme changes in temperature and $\mathrm{pH}$, nutrients depletion, high osmotic pressure, chlorine or ultraviolet light exposure. Under this particular physiological state, bacterial cells maintain their viability properties and active metabolism (albeit with a reduced rate of respiration and gene transcription), while they lose their culturability, becoming not detectable through conventional culture microbiological methods.

Under favorable conditions, VBNC E. coli can resuscitate [3], causing possible health threats following to the ingestion of dormant cells that can recover their virulence and cause gastroenteritis. According to Pinto et al. [3], human intestine represents a favorable environment for bacterial "resuscitation", due to the presence of autoinduction factors (AIs) that are needed to recover viable functions. The ability to multiply is recovered by VBNC cells in short times (about $2 \mathrm{~h}$, [4]). Within the human body, even those E. coli cells that have remained still viable after the osmotic shock caused by seawater salinity are assumed to find in the stomach an environment unsuitable for their survival, conversely, at the intestinal level, all the cells (both those that become VBNC following environmental stress and gastric $\mathrm{pH}$ ) can find a favorable environment, where they can reactivate, so representing a potential risk to bathers.

Current legislation on bathing waters (Bathing Water Directive, 2006/EC) does not consider the different physiological states under which $E$. coli can survive in the environment [5], underestimating the threat related to the resuscitation of VBNC. Moreover, the analytical procedures currently approved do not provide near real-time information on the bacterial load in the marine water bodies, therefore new methodological strategies for detecting bacterial indicators of fecal pollution, that allow the prompt adoption of adequate measures to protect public health, are needed [6].

In this context, the availability of low cost and quick response tools, such as numerical models and satellite imageries, becomes of great relevance to study coastal waters quality [7-10]. In particular the use of numerical models allows to predict the fateof polluted substances in the marine environment, giving an added value to the analysis of the transport and decay of the different physiological states of the E. coli population within a bathing area [11-13]. Moreover, there is an urgent need to develop an index that might integrate the results of the models with the viable (V) and the VBNC E. coli fractions and indicate, with a high spatial resolution, the potential risksrelated to recreational activities.

This study aims at developing a new index, called Bathing Water Quality Index (BWQI), to identify the most suitable marine areas for recreational use taking into account the physiological states of $E$. coli and the effects of hydrodynamic conditions on their spreading in the bathing area.In particular, BWQI was implemented using the models validated by Bonamano et al. [11], which allow to simulate the fate of both $\mathrm{V}$ and total $E$. coli in seawater. To parametrize the different $E$. coli fractions and add the VBNC counts in the set-up of the model thus improving its skills and results reliability, an ad hoc experiment based on the fluorescent antibody method was performed.

\section{Materials and Methods}

\subsection{Study Area and Application of Experimental Circulation Models}

Along the Tyrrhenian coast near Civitavecchia, Latium (Figure 1a,b), the increase of population density during summer season determines a significant increment of the volume of wastewaters that are discharged directly into the sea, without undergoing any 
preliminary depuration treatment. In this coastal zone two bathing areas, "Santa Cecilia" in Civitavecchia and "La Perla del Tirreno" in Santa Marinella, were chosen as study sites.

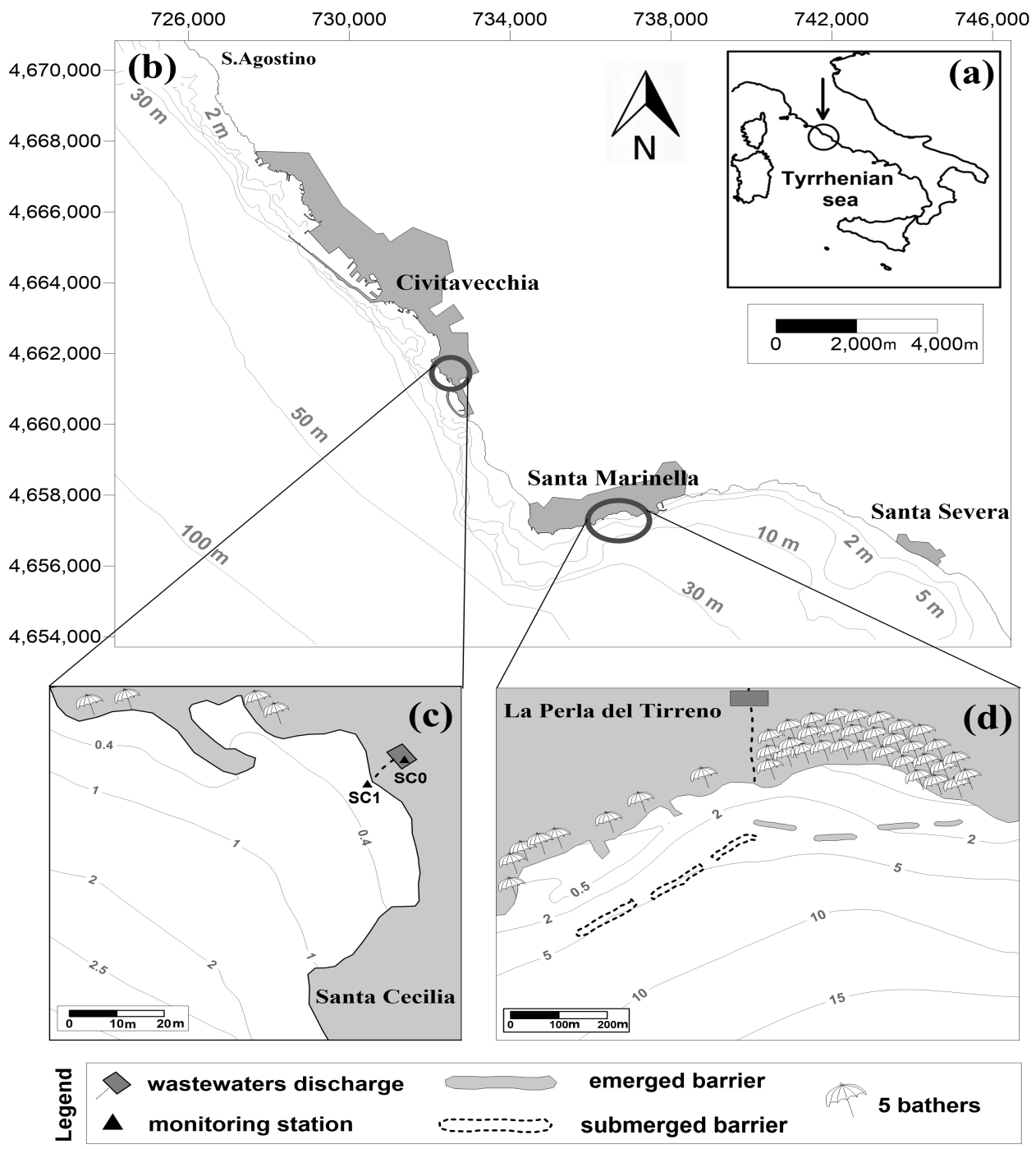

Figure 1. Study area along the Tyrrhenian coast (Latium, Italy, a-b) Location of the Santa Cecilia, Civitavecchia, (c) and of La Perla del Tirreno, Santa Marinella, (d) bathing areas. Both the study sites shows the discharge points and bathers density (one umbrella corresponds to five bathers). The coordinate system is expressed in UTM 32 (WGS84).

Santa Cecilia bathing area (Figure 1c) is located in the southern partof the Civitavecchia coast near a permanent coastal discharge. For these reasons, it is particularly suitable to perform a specific experiment based on fluorescent antibody method as it allows to sample directly inside the overflow basin.

La Perla del Tirreno bathing area (Figure 1d) is located in the centre of the Santa Marinella coast and is characterized by four emerged and three submerged barriers which reduce the water masses circulation and renewal. A discharge point connected to the wastewater pipeline is located between the two main areas: the eastern zone characterized by the highest number of bathers and numerous beach establishments, and the western one with fewer recreational facilities (outlined by the number of umbrellas). It brings untreated waters into the bathing area in case of an overflow situation. Due to these characteristics, La Perla del Tirreno bathing area was considered of interest to study the dynamics of untreated urban wastewaters released into the sea. 


\subsection{In SituSamplings and Physico-Chemical Measurements}

To set up the model taking into account the contribute of VBNC E. coli spread from a generic discharge point, a specific experiment was performed in the Santa Cecilia bathing area (Figure 1), close to Santa Marinella and considered as a suitable site to study the dynamics of untreated urban wastewaters into the sea [14]. In Santa Cecilia, two monitoring stations (SC0 and SC1) were strategically located in an area where wastewaters accumulate before their discharge into the sea and immediately in front of the outflow, respectively. To assess the potential variation of the discharge inputs during the summer season, three field surveys were performed in 2016, on 24 July, on 28 August and on 27 September, respectively. Data provided by the in situ fixed stations of the C-CEMS observing system [15] allowed to describe the meteo-climatic conditions of the sampling days (not shown), reporting a general absence of precipitations during July and August, with a dominance of NE and NW winds, respectively. On the contrary, the September sampling was characterized by SE winds and it was preceded by intense rainfall events from 15 to 21 September, reaching a maximum peak of $10 \mathrm{mmof}$ rain between 16 and 17 September.

Temperature and salinity were measured at each station using an Idronaut 316 multiparametric probe. Subsurface samples $(0.3 \mathrm{~m})$ for microbiological analysis were collected and stored in the dark in sterile containers at a temperature of $4{ }^{\circ} \mathrm{C}$ prior to laboratory analysis, performed within $24 \mathrm{~h}$.

\subsection{Microbiological Measurements}

To quantify the different fractions of E. coli population the methods proposed by Yokomaku et al. [16] and Altug et al. [17] were applied. In particular, viable (V), VBNC, dead (D) and total (T) E. coli, were enumerated, considering that $\mathrm{T}=\mathrm{V}+\mathrm{D}+\mathrm{VBNC}$.

Each sample was divided into 4 sub-volumes $(50 \mathrm{~mL})$, treated as follows:

Protocol A: also known as the direct viable count method, it was adopted for the determination of VBNC E. coli. Two subsamples were prepared, one subjected to a freezing/thawing treatment and one used as control. In particular $40 \mathrm{~mL}$ of both the subsamples were added with $4 \mathrm{~mL}$ of Yeast Extract (at a concentration of $50 \mathrm{mg} / \mathrm{L}$ [16]), $4 \mathrm{~mL}$ of nalidixic acid (at a concentration of $40 \mu \mathrm{g} / \mathrm{mL}$, dissolved in $0.05 \mathrm{M} \mathrm{NaOH}$ ) and $4 \mathrm{~mL}$ of glycine $(2 \%)$ and incubated in the dark for $140 \mathrm{~min}$ at $35^{\circ} \mathrm{C}$. Later, one of the two tubes was frozen at $-20^{\circ} \mathrm{C}$ and thawed at room temperature. Both the tubes were then treated as described in protocol C. After glycine treatment, which induced the transformation of $\mathrm{V}$ cells into spheroplasts, further lysed by the freezing and thawing cycle. the number of the lysed cells corresponded to the number of $V E$. coli. The number of VBNC E. coli was obtained by the difference between $\mathrm{T}$ (obtained from the total abundance estimated in the control tube) and that of V E. coli (obtained after the freezing/thawing process).

Protocol B: applied for the determination of D E. coli. Variable volumes (from 40 to $15 \mathrm{~mL}$ depending on sample contamination) of seawater were filtered through a Millipore black membrane ( $25 \mathrm{~mm}$ diameter, pore size $0.22 \mu \mathrm{m}$ ) (Merck Millipore, Milan, Italy), and incubated with propidium iodide (Sigma-Aldrich, Milan, Italy) at a concentration of $2 \mu \mathrm{g} / \mathrm{mL}$; the membranes were then rinsed with phosphate buffered saline (PBS) and treated as described below in Protocol C.

Protocol C: this analytical protocol is known as the fluorescent antibody method for the determination of T E, coli cells [18], as modified by Caruso et al. [19]. Known volumes (at least $10 \mathrm{~mL}$ ) of formalin fixed sample (final concentration $2 \%$ ) were filtered through a Nuclepore black membrane ( $25 \mathrm{~mm}$ diameter, pore size $0.22 \mu \mathrm{m}$ ) and incubated for $30 \mathrm{~min}$ at room temperature with $1 \mathrm{~mL}$ of a mix of polyclonal immune sera (Behring Serum test Coli anti pool A, B and C, Behring, Marburg, Germany), specific for enteropathogenic E. coli serotypes, diluted 1:80 in PBS. After rinsing with PBS, the filter was incubated for additional 30 min with $1 \mathrm{~mL}$ of anti fluorescein isothiocyanate (FITC) conjugated immunoglobulin (FITC-goat anti-rabbit IgG conjugate, Sigma-Aldrich, Milan, Italy) diluted 1:160 in PBS and rinsed with 
PBS after incubation. All the filters obtained from these protocols -4 filters per each sample, namely two for VBNC cells, one for D cells and one for T cells-were mounted on a slide by inserting a drop of Difco FA mounting fluid (BD, Franklin Lakes, NJ, USA), covered with a coverslip and frozen until observation under epifluorescence microscope (Zeiss Axioplan, Zeiss Oberkochen, Germany) equipped with filter sets specific for FITC (BP450-490, FT510, BP515-565) and propidium iodide (BP546/12; FT580; LP590, the same used for rhodamine).

Finally, the viable fraction $(\mathrm{V})$ was calculated with the formula: $\mathrm{V}=\mathrm{T}-(\mathrm{VBNC}+\mathrm{D})$.

\subsection{Numerical Simulations by Mathematical Models}

To analyze the dispersion and decay of E. coli within the study area, the DELFT3D package was used; it contains the DELFT3D-FLOW hydrodynamic model for the calculation of the sea current, the SWAN model that simulates the wave propagation towards coast and the DELFT3D-WAQ model that analyzes the fate of conservative and non-conservative tracers in the survey area. These mathematical models have already been applied to the "La Perla del Tirreno" bathing area of Santa Marinella to define the dispersion of both V and $\mathrm{T}$ fractions of E. coli population during three days of the 2012 bathing season [11]. Both $\mathrm{V}$ and $\mathrm{T}$ simulations made it possible to forecast with good reliability the $E$. coli distribution patterns in the area and to analyze the bathers' health risk using the flushing time (FT) and Microbiological Potential Risk Area (MPRA).

In this study, a more accurate microbiological water quality analysis has been performed in the same area at four fixed time intervals [Early Morning (EM): 7:00 am-10:00 am; Before Lunch (BL): 10:00 am-1:00 pm; After Lunch (AL): 1:00 pm-4:00 pm; Late Afternoon (LA): 4:00 pm-7:00 pm] in which each of the three sampling days (4 July, 20 August, 12 September) was divided.

The novelty elements of this study are:

(i) the analysis of the dispersion and transport processes of V and VBNC fractions of E. coli population through the use of innovative laboratory protocols;

(ii) the calculation of the FT-related spatial distribution for both V and VBNC fractions;

(iii) the development of an index of water quality that combines the dispersion and transport of $\mathrm{V}$ and VBNC E. coli with their residence times as indicated by FT.

To simulate the dispersion of V and VBNC E. coli within the Santa Marinella bathing area, the same approach reported in Bonamano et al. [11] was applied. Their distribution patterns close to the discharge point were calculated using their relative percentages obtained from the experimental tests conducted during summer 2016. In particular, the E. coli physiological states were used for the set-up of the model as detailed in Section 3.1.

For each sampling day, four simulations were carried out corresponding to the considered time intervals. Each simulation covered $3 \mathrm{~h}$, during which a constant bacterial load was assumed to be released by the discharge point. The resulting bacterial concentrations have been depth- and time- averaged and subsequently assigned to four water quality classes (excellent, good, sufficient and poor),defined by the Italian Legislative Decree 116/2008. To improve water quality assessment, a further water quality class was added, defined as "No Bathing", assigned to waters with E. coli concentrations exceeding $500 \mathrm{MPN} / 100 \mathrm{~mL}$. The FT in the bathing area was calculated assuming the release of a known concentration of $\mathrm{V}$ and VBNC cells inside the study area during the four time intervals. FT values have been then calculated by applying the remnant function [20] to the 24 simulations that reproduce the behavior of $\mathrm{V}$ and VBNC E. coli (4 time periods $\times 3$ sampling days = 12 simulations per each physiological state).

The bacterial load and its associated FT were used to build the BWQ Index which takes into account both $\mathrm{V}$ and VBNC fractions of the $E$. coli population, providing information on bathing waters quality. Before setting up the index, both the bacterial load and FT values were converted into a $0-1$ range. In detail, $\mathrm{V}$ and $\mathrm{VBNC}$ abundances were arbitrarily assigned to the five quality classes: 1 (excellent), 0.8 (good), 0.6 (sufficient), 0.3 (poor) and 0 (nobathing); FT values were also classified into five classes as follows: 1 for FT values < 
$60 \mathrm{~min}$; 0.8 for $60<\mathrm{FT}<180 \mathrm{~min} ; 0.6$ for $180<\mathrm{FT}<360 \mathrm{~min} ; 0.3$ for $360<\mathrm{FT}<720 \mathrm{~min}$; 0.1 for FT $>720 \mathrm{~min}$. The lowest FT value was assigned to waters in which the bacterial load remains longer than the duration of a bathing day $(12 \mathrm{~h})$; in this case, the bather has a very high probability to enter in contact with E. coli, and the health risks increase. The FT value increases when the exposure time of bathers to the bacterial load decreases, reaching a maximum value of 1 which is assigned to a residence time of the bacterial load shorter than one hour.

The normalized V and VBNC concentrations and FT values were used to calculate the index BWQI, which is given by the following formula:

$$
\mathrm{BWQI}=a \times \text { mean }(\text { Cnorm V, FTnorm V) }+b \times \text { mean }(\text { Cnorm VBNC, FTnorm VBNC) }
$$

where a and $b$ represent the percentage contribution of $\mathrm{V}$ and $\mathrm{VBNC}$ fractions and mean is the arithmetic mean function calculated from Cnorm V (Cnorm VBNC) and FTnorm V (FTnorm VBNC) values, that are the concentration and FT classes of the V (or VBNC) fraction.

In this study $a$ and $b$ values have been set equal to 0.5 , considering that both the $\mathrm{V}$ and VBNC fractions can potentially represent the same hazard to bathers' health. Moreover, the mean function was used to attribute to the concentration and residence time terms the same relevance in the framework of the quality assessment process.

\section{Results}

\subsection{Estimation of the E. coli Fractions Discharged into Seawater}

Data obtained from the experimental testsperformed during summer 2016 (Figure 2) allowed to describe within an active sewage effluent the presence of different physiological states of E. coli and their changes after their arrival into the sea. In particular, two main scenarios, differing in cell physiological attributes, have been detected in relation to the occurrence of rainfall events. In the first scenario (no precipitation, NP), typical of the summer months (July and August) characterized by long drought periods, sewages were characterized by high percentages of V E. coli (about $45-75 \%$ of the total) and low percentages of D and VBNC E. coli(from 25 to 35\%), highlighting the active discharge of wastewaters at station SC0. After having reached the sea (station SC1), V E. coli decreases to $10-20 \%$ of the total population, while D and VBNC ones increase to $55-60 \%$ and $20-25 \%$ respectively, in response to the adverse environment they are exposed to. In the second scenario (precipitation, P), which occurs after an intense rainfall event (as in September 2016), the wastewater flux is high, consequently no quantitative differences are observed inside and immediately outside the discharge point, and V, D and VBNC E. coli account for 6,60 and $35 \%$, respectively.

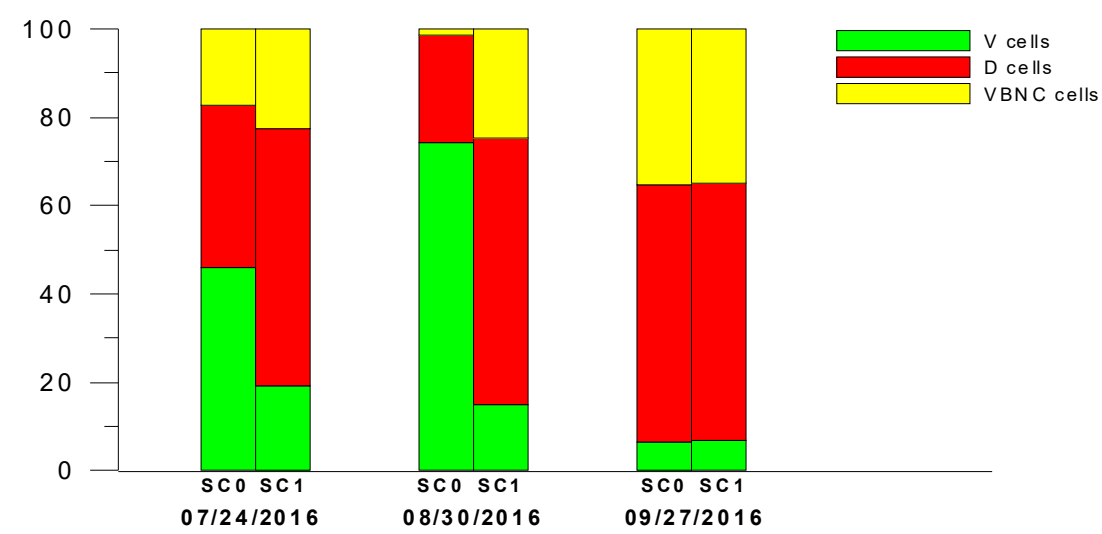

Figure 2. Percentage contribution to total E. coli population of viable (V), dead (D) and viable but not culturable (VBNC) fractions observed at the wastewater discharge (SC0) and monitoring (SC1) sites in Santa Cecilia during summer 2016. 
Based on these results, the above-reported conditions were applied to set-up the model for the July and August simulations (NP) and September one (P), respectively. Moreover, taking into account that the discharge point was located in the middle of the La Perla del Tirreno bathing area, an increment of the flux by $20 \%$ (NP) and $67 \%$ (P) respectively was considered to simulate the E. coli load released into the seaas likely as possible.

\subsection{Dispersion and Residence Times of E. coli Fractions}

The percentages of V and VBNC E. coli measured at the discharge point were used to simulate the transport of live and dormant bacteria within La Perla del Tirreno bathing area. In detail, 24 simulations were carried out in order to assess the bathing waters quality in relation with $\mathrm{V}$ and VBNC E. coli potentially present during three sampling days of summer 2012 and during four daily periods. The microbiological quality classes have been established according to the limit values reported in Legislative Decree $116 / 2008$, which classifies bathing waters into five quality classes: banned for bathing use (colored in red), poor (orange), sufficient (yellow), good (green) and excellent quality (light blue).

Taking into consideration both V and VBNC E. coli, La Perla del Tirreno bathing area falls in the poor quality class (Figures 3 and 4) during the 20 August sampling. In this period the banned zone reaches its maximum extension, especially in the afternoon when a worsening of seawater quality is recorded in coincidence with the highest recreational use. Significant decrease of microbiological quality occurs also in the AL period on 4 July and in the morning on 12 September; this, however, is mainly related to VBNC E. coli. Bathing waters reach good and excellent quality during the EM period on 4 July and in the afternoon on 12 September, both for V and VBNC E. coli.
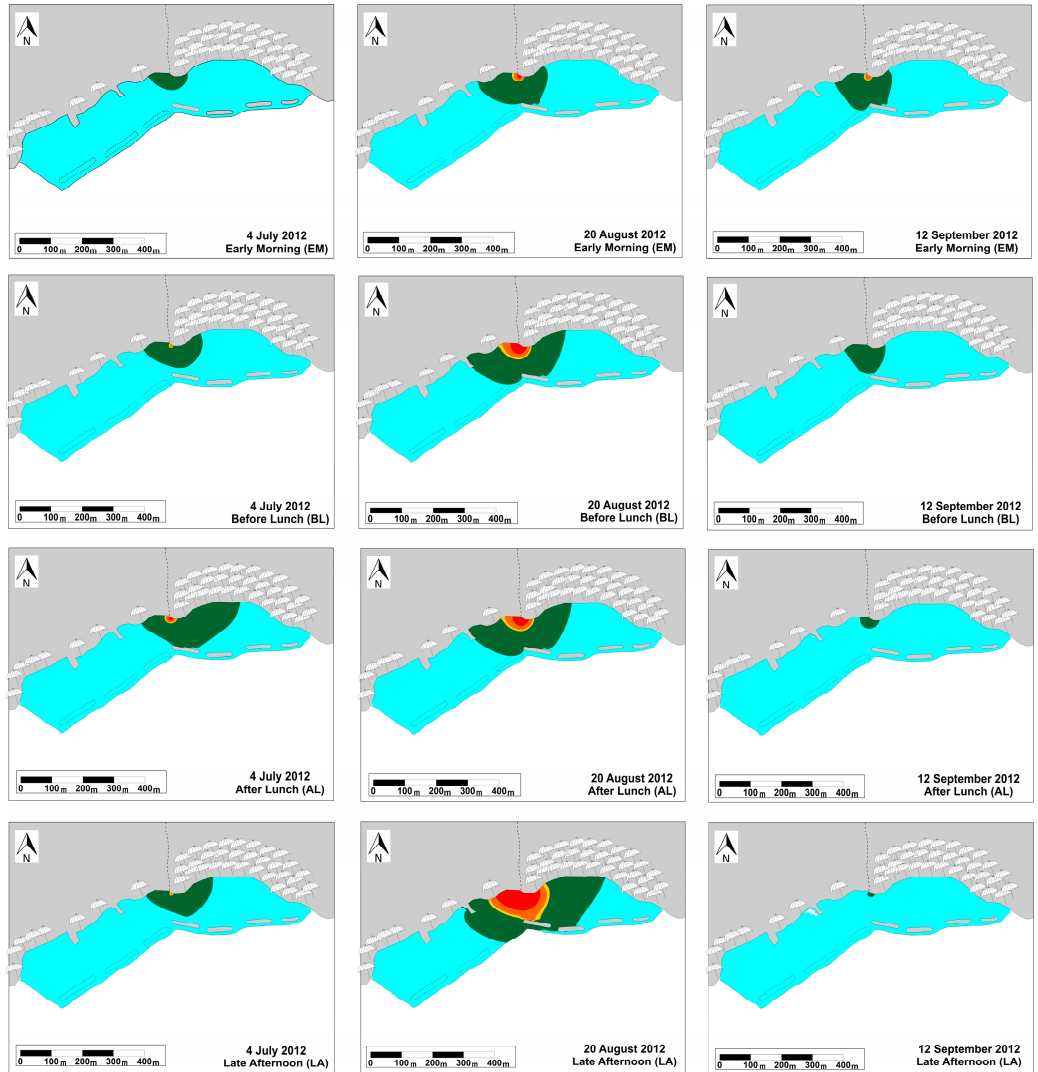

Figure 3. Concentration of living E. coli within the classified survey area according to the water quality criterion reported in the Legislative Decree 116/2008 (red = water banned for bathing use; orange = poor quality; yellow = sufficient quality; green = good quality; light blue = excellent quality). The microbiological water quality within La Perla del Tirreno bathing area was calculated in the three sampling days of summer 2012 (July, August, September, in columns) and the four considered daily periods (in rows). 

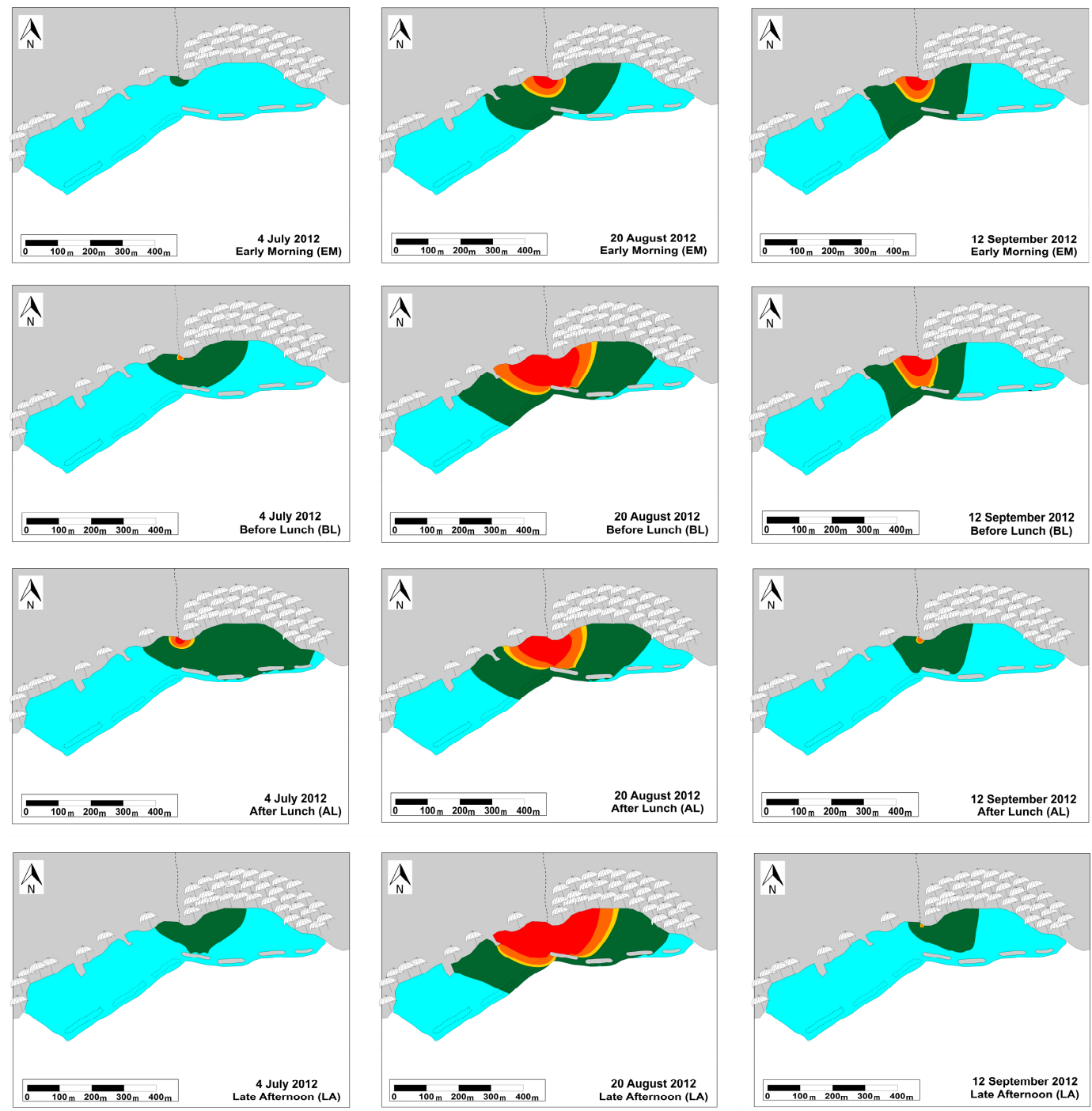

Figure 4. Concentration of VBNC E. coli within the classified survey area according to the water quality criterion reported in the Legislative Decree 116/2008 (red = water banned for bathing use; orange = poor quality; yellow = sufficient quality; green = good quality; light blue = excellent quality). The microbiological water quality within La Perla del Tirreno bathing area was calculated in the three sampling days of summer 2012 (July, August, September, in columns) and the four considered daily periods (in rows).

The quality of bathing waters was also assessed on the basis of the time (Flushing Time, FT) required by the most of bacterial load (about 63\%) to be removed away from the bathing area by the transport processes towards the off-shore zone as well as by the bacterial decay due to adverse environmental conditions. FT was evaluated for both the V (Figure 5) and the VBNC E. coli (Figure 6) in the same summer days and time periods previously considered in Figures 3 and 4. 

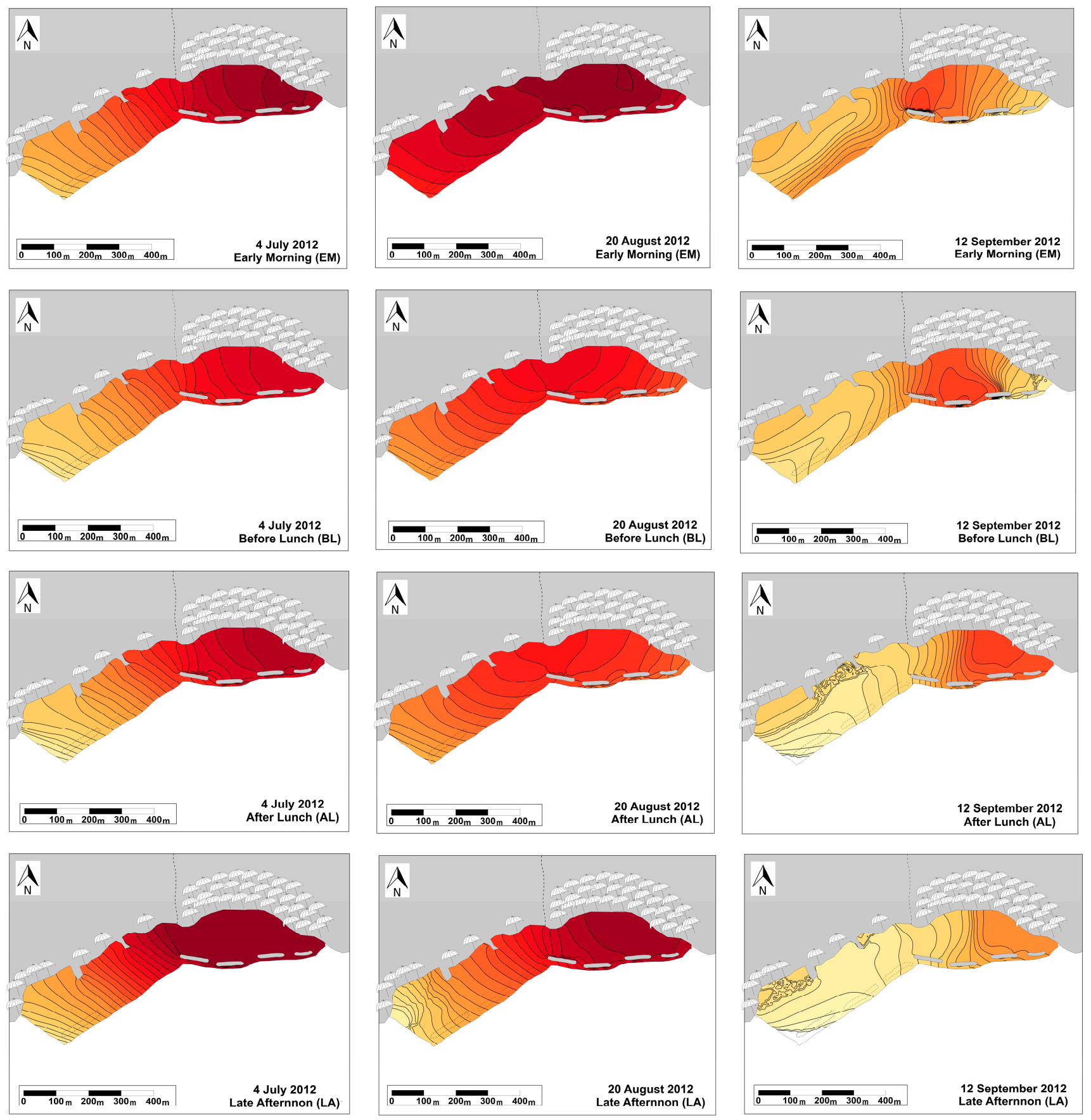

Flushing time (minutes)

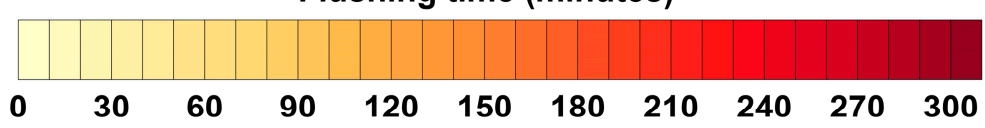

Figure 5. Flushing Time calculated on the viable E. coli (FT-V) within La Perla del Tirreno bathing area. FT-V is represented in the three sampling days of summer 2012 (July, August, September, in columns) and in the four daily periods (in rows). 

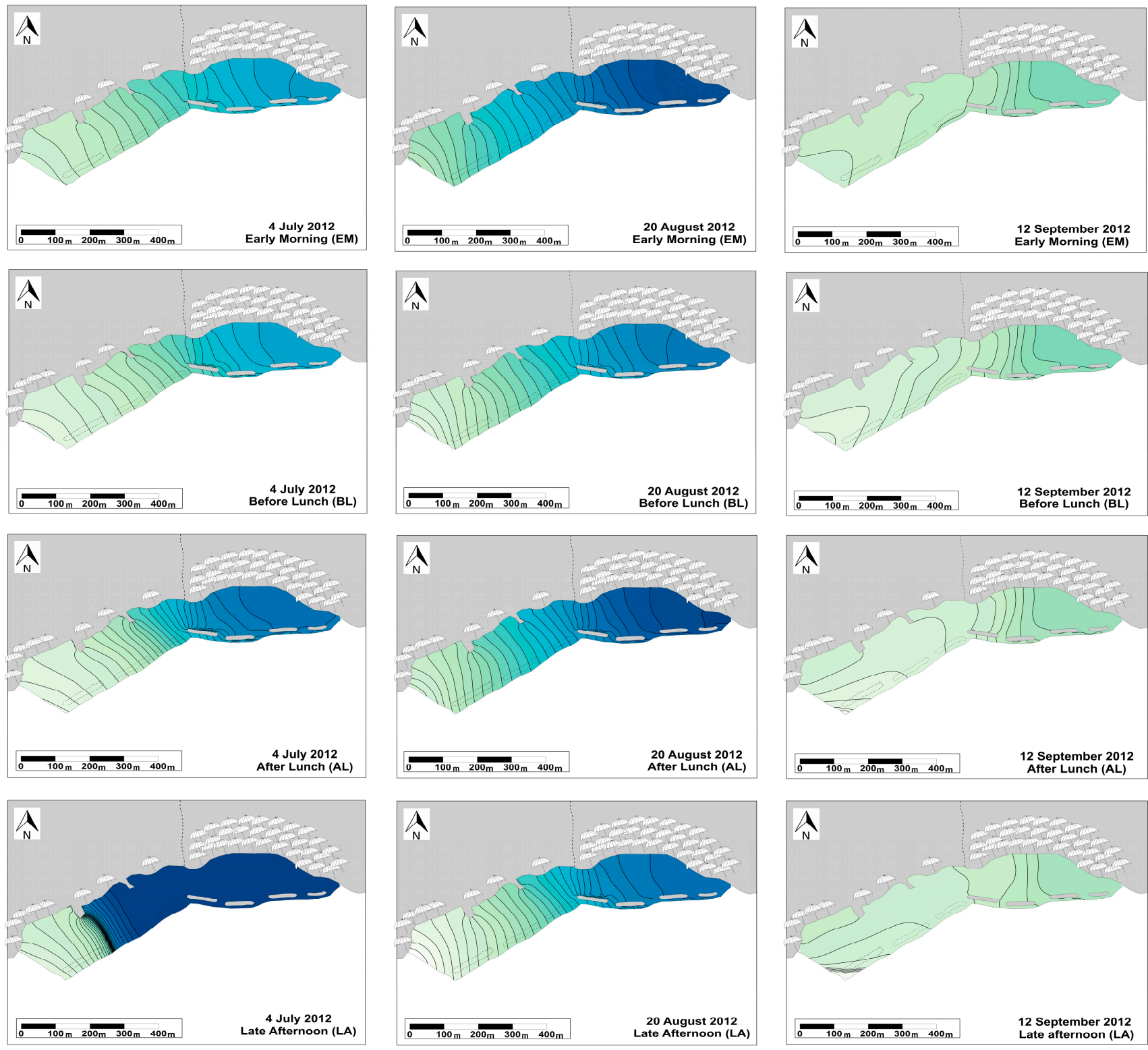

Flushing time (minutes)

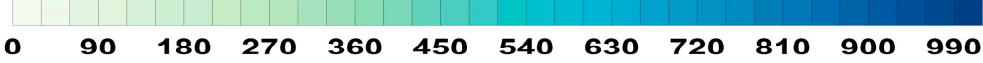

Figure 6. Flushing Time calculated on the VBNC E. coli (FT-VBNC) within La Perla del Tirreno bathing area. FT-VBNC is represented in the three sampling days of summer 2012 (July, August, September, in columns) and in the four daily periods (in rows).

The residence time of $\mathrm{V}$ E. coli ranges from values close to $0 \mathrm{~min}$ in the western part of the study area to $300 \mathrm{~min}$ in the eastern zone, where bathers are present in high numbers (Figure 5). In particular, the highest FT values, with consequent longest water renewal, are observed throughout all the day on 4 July and at the earlier (EM) and latest (LA) daytime samplings on 20 August. On the other hand, shorter renewal times are calculated on 12 September, when FT values are approximately half $(180 \mathrm{~min})$ of those recorded in the two other samplings.

For the VBNC E. coli (Figure 6), FT values much higher compared to the V E. coli have been obtained, with maximum values of $960 \mathrm{~min}$ calculated in the easternmost zone of the bathing area. The longest renewal times are found on 20 August and in the last (LA) 
daytime period on 4 July; while shortest values of FT are observed on 12 September when values lower than $300 \mathrm{~min}$ are recorded.

\subsection{BWQI Development and Application}

The BWQ Index was developed taking into account the transport of V and VBNC E. coli spilled in the centre of Santa Marinella bathing area from a discharge point and their residence time within the study area. Index values close to 1 indicate a good microbiological quality of the bathing waters while values close to 0 define a very bad microbiological quality, with a consequently high potential risk to human health.

In this survey, low BWQ Index values are found in correspondence of the discharge point and in the western part of the bathing area, where the presence of emerged barriers limits the water exchange with the off-shore area. In the western part of bathing zone, the lowest BWQI values are observed during late afternoon on 4 July, while the highest ones on 12 September, indicating a good bathing water quality (Figure 7).
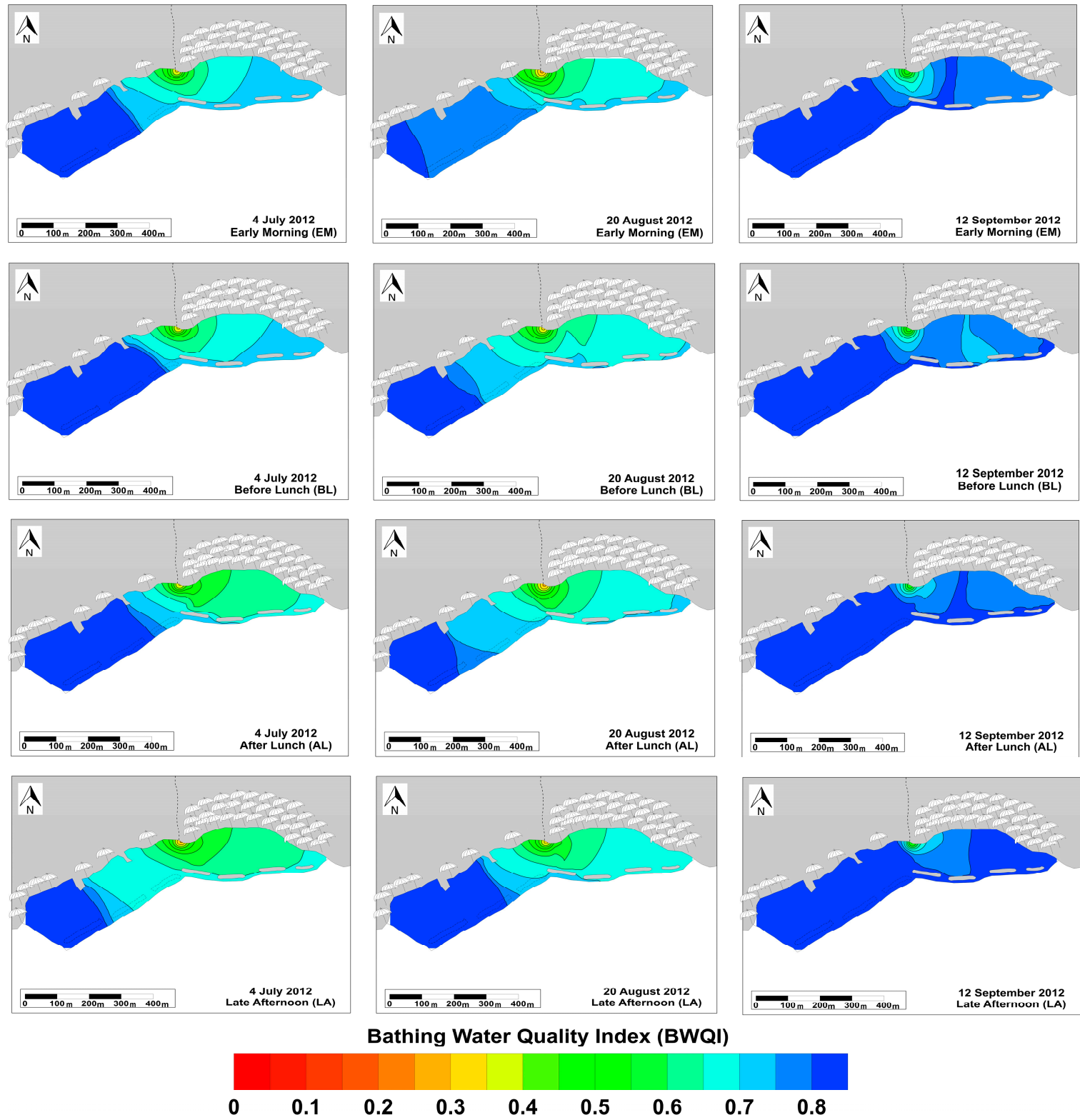

Figure 7. Spatial variation of the BWQI values within La Perla del Tirreno bathing area, reported in the three sampling days of summer 2012 (July, August, September, in columns) and in the four daily time periods (in rows). 


\section{Discussion}

Marine environments are one of the Earth's most valuable natural resources, providing ecosystem services such as food resources, recreational activities and tourism; about $40 \%$ of the world population lives within $100 \mathrm{~km}$ from the coast, therefore there is an urgent need to preserve their integrity and warrant their sustainable use for future generations. Knowledge of the marine ecosystems health status and of the mechanisms ruling their functioning is a priority in this context. Increasing the observational and forecasting capabilities contributes to assess and understand the possible impacts of anthropic pressures on marine environments; consequently, observational systems must provide adequate information on the environmental status in order to allow sustainable use of resources and of related ecosystem services [21]. There are many research initiatives that focus on the sea and the management of natural assets based on an integrated and multidisciplinary context [22]. For example, Marine Strategy Framework Directive (2008/56/EC [23]) promotes the achievement of the Good Environmental Status (GES) and of healthy and productive waters, able to provide goods, services and wellness; due to the great complexity of the marine ecosystems, acquisition of environmental data must be strictly connected with data analysis, in an integrated approach towards coastal and biological observations [24].

E. coli is commonly associated with the gastrointestinal tract of humans, warm-blooded animals and reptiles [25], and its presence in external environments such as subtropical waters and sediments gives an indication that recent fecal contamination has occurred [26]. This niche specificity justifies its use as an indicator of fecal contamination in the environment, where it can persist and grow. The survival of fecal bacteria in coastal waters depends on physico-chemical and hydrodynamic conditions [27]. Entrance into a VBNC state has been demonstrated for a number of bacteria, including E. coli [28,29]; for this microorganism, however, the occurrence of "naturalized" populations adapted to survive in the environment has also been proposed [30,31], On the other hand, the resuscitation of bacterial pathogens and indicator microorganisms is still a concept under debate [4,32-34]. To date, estimates of the "resuscitation ratio" of VBNC E. coli have documented only the possibility of resuscitating VBNC in microcosms that simulate the natural environment [35,36], and consequently the potential human health hazards [37], without indicating the percentages of resuscitation. A recent systematic review and meta-analysis of epidemiological studies regarding the acquisition of infections in bathers compared to non-bathers has confirmed that several infections arise following exposure to contaminated waters [38].

The methodology proposed in this study allowed to analyze the dispersion of both $\mathrm{V}$ and VBNC E. coli. In order to properly evaluate the microbiological water quality, BWQI has been developed to identify the most favorable coastal zones for recreational use taking into account the hydrodynamic conditions and the physiological state of E. coli cells. This index was applied to La Perla del Tirreno (Santa Marinella, Italy) bathing area, that, like many other Italian bathing areas hosting intense touristic activities, is characterized bythe presence of emerged and submerged barriers that protect the coast from erosion but, at the same time, hinder the dilution process of potentially contaminated water masses due to the limitation of exchanges with the off-shore area. Moreover, a discharge point connected to the wastewater pipeline is located between Santa Cecilia and La Perla del Tirreno, releasing untreated waters into the bathing areas in case of an overflow situation [11]. These features make these areas particularly vulnerable to microbiological pollution phenomena that, in turn, can damage bathers' health.

BWQI calculation is based on the results of the DELFT3D package numerical models that simulate the transport, dispersion and decay of V and VBNC E. coli, as well as their residence times (or Flushing Time, FT) inside the bathing areas. Compared to the previous model application [11], the main novelty of this index concerns the simulation of $\mathrm{V}$ and VBNC E. coli by using the percentages of these physiological states estimated with specific experimental assays performed in summer 2016 in the Santa Cecilia. This bathing area, close to La Perla del Tirreno, has been selected for the possibility to sample inside the overflow basin. For this purpose, three field surveys have been carried out, characterized 
by meteo-climatic conditions similar to those of summer 2012, when the dataset for the validation of the models was collected considering the total E. coli population close to the wastewater discharge of the Santa Marinella only [11]. The percentages of V and VBNC E. coli found in the test area of Santa Cecilia have made it possible to estimate the abundance of the two E. coli fractions upstream the discharge point.

The simulation of the transport of pathogens within La Perla del Tirreno bathing area has highlighted that the no-bathing zone reaches a maximum extension in the late evening of 20 August, when the low water quality is associated to VBNC E. coli. Even though VBNC fraction could represent a public health hazard, this component is not yet monitored or included within standard protocols in use for evaluating the microbiological bathing water quality [39].

In addition to cell physiological states, another useful parameter to assess bathing waters quality is represented by FT that, describing the time required by most of the bacterial load to move away from the bathing area, is indicative of its vulnerability to pollution $[40,41]$. Once again, the renewal time estimated for VBNC E. coli has resulted to be about 3 times longer than for $\mathrm{V}$ ones, confirming the high potential risks that VBNC cells expose bathers to. It should also be emphasized that the highest FT values recorded for both V and VBNC E. coli during the EM and LA periods on 4 July and 20 August have been observed in the eastern area, more frequented by bathers.

The BWQI has been developed assuming that VBNC cells are able to resuscitate inside human body [11]. The same probability has been attributed to the parameters related to the dispersion of bacteria from the discharge point and their residence time within the bathing area. Like the method adopted to analyze the risk of water quality degradation [40], it has been hypothesized that the dispersion of bacteria, linked to the exposure of the water body to pollution events, and FT, which represents the vulnerability of the water masses, assume the same importance in the microbiological quality assessment. Both these parameters have been reported to range between 0 and 1 . E. coli concentrations have been assigned to the water quality classes defined by the Italian Legislative Decree 116/2008, plus a further quality one, called "No Bathing", reached when the bacterial concentration exceeds 500 MPN/100 mL. With the same approach, also FT values have been assigned to five classes, in terms of thetime-related probability for bathers to enter into contact with contaminated waters, with lower values assigned to water masses in which bacteria remain for a longer time. As observed, high values (close to 1) have been found when the bacterial load is quickly diluted during a rainfall event, as observed in September.

The new BWQI made it possible to forecast the bathing water quality in four distinct periods of a bathing day, defined considering the different number and age of bathers. The analysis proposed in this study overcomes the limits of the current legislation which assesses the microbiological quality exclusively on the basis of viable bacteria counted at fixed stations within the bathing area. The BWQI distribution patterns have indeed shown that there is a high spatial variability within the study area. The area most frequented by bathers has a low water quality in the afternoon on 4 July, although the highest concentration of V and VBNC E. coli is found on 20 August. To make BWQI time predictions, it is necessary to assimilate into the model the continuous in situ measurements acquired at the discharge source.

The preliminary results of this study have shown that BWQI provides useful information at a high spatial resolution for the identification of the marine areas characterized by good quality. To improve the performance of BWQI it will be important to simulate the dynamics of the different physiological states of E. coli population according to the physico-chemical variations. Moreover, the application of BWQI to other bathing areas surrounded by barriers could allow to detect potentially microbial polluted zones, so enabling local Authorities to identify concrete mitigation measures (i.e., the use of eco-friendly submerged barriers or promoting the adoption of nature-based solutions) to reduce the risks to bathers health. 
In the perspective of environmental protection, this study represents a further step towards the set up of a coastal observing system, developing new management solutions and implementing the capability of the existing Civitavecchia Coastal Environment Monitoring System C-CEMS in forecasting potential pollution phenomena $[14,15]$. The development of a forecasting system integrated with in situ real-time measures would be fundamental to support local Authorities on the management of emergency discharge events, thus limiting the risk to bathers' health coming from fecal bacteria.

The estimates provided by this study could be helpful in limiting the risk for human's health related to fecal pollution, offering to local Authorities a tool for planning in advance the closure of beaches; moreover, the possibility to perform continuous, real-time measurements of the bacteriological quality of marine waters inside or close to the wastewater discharge through cost-effective technologies can further improve environmental and human safeguard, providing essential time-series to set up early-warning monitoring networks allowing to identify the exceeded bathing limits and the subsequent "near real-time" forecasting of bathing water quality.

\section{Conclusions}

An ad hoc experiment based on the fluorescent antibody method has been performed to simulate the dynamics of different physiological states of E. coli after their discharge into the marine environment. In the view of possible forecast of bathing waters suitability, especially where barriers are limiting water mass circulation, simulations with mathematical models of the distribution of V and VBNC E. coli have been performed under three different environmental scenarios (early, middle and late summer periods), allowing to assess the distribution of E. coli and potential risks for human health. Based on the model outputs, a new Bathing Water Quality Index has been set up. BWQI includes the Flushing Time which takes into account the morphology of the area, the meteomarine conditions and the physiological state of E. coli cells. It ranges from 0 to 1 , from worst to best water quality condition. Its application to Santa Marinella bathing area highlights a potential risk to human health in the area most frequented by bathers. This study proposes a lowcost and predictive tool, that can be easily exported and applied to other semi-enclosed bathing areas, to correctly address the needs of environmentally sustainable and public health management.

Author Contributions: Conceptualization, S.B. and A.M.; methodology, A.M., G.C.; software, S.B.; validation, S.B., A.M. and M.M.; formal analysis, G.Z.; investigation, S.B., G.C. and A.M.; resources, G.C., M.M.; data curation, S.B., A.M., G.C.; writing-original draft preparation, all the authors; writing-review and editing, all the authors.; visualization, G.Z.; supervision, S.B., A.M., G.Z.; funding acquisition, M.M. All authors have read and agreed to the published version of the manuscript.

Funding: This research received no external funding.

Institutional Review Board Statement: Not applicable.

Informed Consent Statement: Not applicable.

Data Availability Statement: The data presented in this study are available on request from the corresponding author. The data are not publicly available due to privacy restriction.

Conflicts of Interest: The authors declare no conflict of interest.

\section{References}

1. Pinto, D.; Santos, M.A.; Chambel, L. Thirty years of viable but nonculturable state research: Unsolved molecular mechanisms. Crit. Rev. Microbiol. 2015, 41, 61-76. [CrossRef] [PubMed]

2. Hassard, F.; Andrews, A.; Jones, D.L.; Parsons, L.; Jones, V.; Cox, B.A.; Daldorph, P.; Brett, H.; McDonald, J.E.; Malham, S.K. Physicochemical factors influence the abundance and culturability of human enteric pathogens and fecal indicator organisms in estuarine water and sediment. Front. Microbiol. 2017, 8, 1996. [CrossRef] [PubMed]

3. Pinto, D.; Almeida, V.; Almeida Santos, M.; Chambel, L. Resuscitation of Escherichia coli VBNC cells depends on a variety of environmental or chemical stimuli. J. Appl. Microbiol. 2011, 110, 1601-1611. [CrossRef] 
4. Ohtomo, R.; Saito, M. Increase in the culturable cell number of Escherichia coli during recovery from saline stress: Possible implication for resuscitation from the VBNC state. Microb. Ecol. 2001, 42, 208-214. [CrossRef] [PubMed]

5. Caruso, G.; Mancuso, M.; Crisafi, E. Combined fluorescent antibody assay and viability staining for the assessment of the physiological states of Escherichia coli in seawaters. J. Appl. Microbiol. 2003, 95, 225-233. [CrossRef] [PubMed]

6. Caruso, G.; Denaro, R.; Genovese, M.; Giuliano, L.; Mancuso, M.; Yakimov, M. New methodological strategies for detecting bacterial indicators. Chem. Ecol. 2004, 20, 167-181. [CrossRef]

7. Bonamano, S.; Madonia, A.; Piazzolla, D.; Paladini de Mendoza, F.; Piermattei, V.; Scanu, S.; Marcelli, M. Development of a predictive tool to support environmentally sustainable management in port basins. Water 2017, 9, 898. [CrossRef]

8. Salmoun, F.; El Yemlahi, A.; Magalhaes, J.M. Monitoring Tangier (Morocco) coastal waters for As, Fe and P concentrations using ESA Sentinels-2 and 3 data: An exploratory study. Reg. Stud. Mar. Sci. 2019, 32, 100882. [CrossRef]

9. Cherif, E.K.; Salmoun, F.; Mesas-Carrascosa, F.J. Determination of bathing water quality using thermal images Landsat 8 on the west coast of Tangier: Preliminary results. Remote Sens. 2019, 11, 972. [CrossRef]

10. Piazzolla, D.; Cafaro, V.; de Lucia, G.A.; Mancini, E.; Scanu, S.; Bonamano, S.; Piermattei, V.; Vianello, A.; Della Ventura, G.; Marcelli, M. Microlitter pollution in coastal sediments of the northern Tyrrhenian Sea, Italy: Microplastics and fly-ash occurrence and distribution. Estuar. Coast. Shelf Sci. 2020, 241, 106819. [CrossRef]

11. Bonamano, S.; Madonia, A.; Borsellino, C.; Stefanì, C.; Caruso, G.; De Pasquale, F.; Piermattei, V.; Zappalà, G.; Marcelli, M. Modeling the dispersion of viable and total Escherichia coli cells in the artificial semi-enclosed bathing area of Santa Marinella (Latium, Italy). Mar. Pollut. Bull. 2015, 95, 141-154. [CrossRef] [PubMed]

12. Zappalà, G.; Caruso, G.; Bonamano, S.; Madonia, A.; Piermattei, V.; Martellucci, R.; Di Cicco, A.; Pannocchi, A.; Stefanì, C.; Borsellino, C.; et al. A multi-platform approach to marine environment assessment in the Civitavecchia (Rome) area. J. Oper. Oceanogr. 2016, 9 (Suppl. 1), S131-S143. [CrossRef]

13. Ostoich, M.; Ghezzo, M.; Umgiesser, G.; Zambon, M.; Tomiato, L.; Ingegneri, F.; Mezzadri, G. Modelling as decision support for the localisation of submarine urban wastewater outfall: Venice lagoon (Italy) as a case study. Environ. Sci. Pollut. Res. 2018, 25, 34306-34318. [CrossRef]

14. Madonia, A.; Caruso, G.; Piazzolla, D.; Bonamano, S.; Piermattei, V.; Zappalà, G.; Marcelli, M. Chromophoric Dissolved Organic Matter as a tracer of fecal contamination for bathing water quality monitoring in the northern Tyrrhenian Sea (Latium, Italy). J. Mar. Sci. Eng. 2020, 8, 430. [CrossRef]

15. Bonamano, S.; Piermattei, V.; Madonia, A.; Paladini de Mendoza, F.; Pierattini, A.; Martellucci, R.; Stefanì, C.; Zappalà, G.; Caruso, G.; Marcelli, M. The Civitavecchia Coastal Environment Monitoring System (C-CEMS): A new tool to analyze the conflicts between coastal pressures and sensitivity areas. Ocean Sci. 2016, 12, 87-100. [CrossRef]

16. Yokomaku, D.; Yamaguchi, N.; Nasu, M. Improved Direct Viable Count procedure for quantitative estimation of bacterial viability in freshwater environments. Appl. Environ. Microbiol. 2000, 66, 5544-5548. [CrossRef]

17. Altug, G.; Cardak, M.; Ciftci, P.S.; Gurun, S. The application of viable count procedures for measuring viable cells in the various marine environments. J. Appl. Microbiol. 2010, 108, 88-95. [CrossRef]

18. Zaccone, R.; Crisafi, E.; Caruso, G. Evaluation of fecal pollution in coastal Italian waters by immunofluorescence. Aquat. Microb. Ecol. 1995, 9, 79-85. [CrossRef]

19. Caruso, G.; Zaccone, R.; Crisafi, E. Use of the indirect immunofluorescence method for detection and enumeration of Escherichia coli in seawater samples. Lett. Appl. Microbiol. 2001, 31, 274-278. [CrossRef]

20. Takeoka, H. Fundamental concepts of exchange and transport time scales in a coastal sea. Contin. Shelf Res. 1984, 3, 311-326. [CrossRef]

21. Benedetti-Cecchi, L.; Crowe, T.; Boehme, L.; Boero, F.; Christensen, A.; Grémare, A.; Hernandez, F.; Kromkamp, J.C.; Nogueira Garcia, E.; Petihakis, G.; et al. Strengthening Europe's capability in biological ocean observations. In EMB Future Science Brief 3 of the European Marine Board; Muñiz Piniella, A., Kellett, P., Larkin, K., Heymans, J.J., Eds.; European Marine Board: Ostend, Belgium, 2018; pp. 1-76. ISBN 9789492043559.

22. Elliott, M.; Boyes, S.J.; Barnard, S.; Borja, A. Using best expert judgement to harmonize marine environmental status assessment and maritime spatial planning. Mar. Pollut. Bull. 2018, 133, 367-377. [CrossRef] [PubMed]

23. European Commission. Directive 2008/56/EC of the European Parliament and of the Council of the 17 June 2008 establishing a framework for Community actions in the field of marine environmental policy (Marine Strategy Framework Directive). OJEC 2008, L164, 19-40.

24. She, J.; Muñiz Piniella, Á.; Benedetti-Cecchi, L.; Boehme, L.; Boero, F.; Christensen, A.; Crowe, T.; Darecki, M.; Nogueira, E.; Gremare, A.; et al. An integrated approach to coastal and biological observations. Front. Mar. Sci. 2019, 6, 314. [CrossRef]

25. Berg, R.D. The indigenous gastrointestinal microflora. Trends Microbiol. 1996, 4, 430-435. [CrossRef]

26. Anderson, K.L.; Whitlock, J.E.; Harwood, V.J. Persistence and differential survival of fecal indicator bacteria in subtropical waters and sediments. Appl. Environ. Microbiol. 2005, 71, 3041-3048. [CrossRef]

27. Korajkic, A.; Wanjugi, P.; Brooks, L.; Cao, Y.; Harwood, V.J. Persistence and decay of fecal microbiota in aquatic habitats. Microbiol. Mol. Biol. Rev. 2019, 83, e00005-19. [CrossRef]

28. Fakruddin, M.D.; Shahneway Bin Mannan, K.; Andrews, S. Viable but Nonculturable Bacteria: Food safety and public health perspective. ISRN Microbiol. 2013. [CrossRef] 
29. Ding, T.; Suo, Y.; Xiang, Q.; Zhao, X.; Chen, S.; Ye, X.; Liu, D. Significance of Viable but Nonculturable Escherichia coli: Induction, detection, and control. J. Microbiol. Biotechnol. 2017, 27, 417-428. [CrossRef]

30. Ishii, S.; Sadowsky, M.J. Escherichia coli in the environment: Implications for water quality and human health. Microbes Environ. 2008, 23, 101-108. [CrossRef]

31. Jang, J.; Hur, H.-G.; Sadowsky, M.J.; Byappanahalli, M.N.; Yan, T.; Ishii, S. Environmental Escherichia coli: Ecology and public health implications-a review. J. Appl. Microbiol. 2017, 123, 570-581. [CrossRef]

32. Kell, D.B.; Kaprelyants, A.S.; Weichart, D.H.; Harwood, C.R.; Barer, M.R. Viability and activity in readily culturable bacteria: A review and discussion of the practical issues. Antonie van Leeuwenhoek 1998, 73, 169-187. [CrossRef] [PubMed]

33. Arana, I.; Orruño, M.; Pérez-Pascual, D.; Seco, C.; Muela, A.; Barcina, I. Inability of Escherichia coli to resuscitate from the viable but nonculturable state. FEMS Microbiol. Ecol. 2007, 62, 1-11. [CrossRef] [PubMed]

34. Orruño, M.; Kaberdin, V.R.; Arana, I. Survival strategies of Escherichia coli and Vibrio spp.: Contribution of the viable but nonculturable phenotype to their stress-resistance and persistence in adverse environments. World J. Microbiol.Biotechnol. 2017, 33, 45. [CrossRef] [PubMed]

35. Liu, Y.; Wang, C.; Tyrrell, G.; Hrudey, S.E.; Li, X.F. Induction of Escherichia coli O157:H7 into the viable but non-culturable state by chloraminated water and river water, and subsequent resuscitation. Environ. Microbiol. Rep. 2009, 1, 155-161. [CrossRef]

36. Özkanca, R.; Saribiyik, F.; Isik, K.; Sahin, N.; Kariptas, E.; Flint, K.P. Resuscitation and quantification of stressed Escherichia coli K12 NCTC8797 in water samples. Microbiol. Res. 2009, 164, 212-220. [CrossRef]

37. Li, L.; Mendis, N.; Trigui, H.; Oliver, J.D.; Faucher, S.P. The importance of the viable but non-culturable state in human bacterial pathogens. Front. Microbiol. 2014, 5, 258. [CrossRef]

38. Leonard, A.F.C.; Singer, A.; Ukoumunne, O.C.; Gaze, W.H.; Garside, R. Is it safe to go back into the water? A systematic review and meta-analysis of the risk of acquiring infections from recreational exposure to seawater. Int. J. Epidemiol. 2018, 47, 572-586. [CrossRef]

39. Caruso, G.; La Ferla, R.; Azzaro, M.; Zoppini, A.; Marino, G.; Petochi, T.; Corinaldesi, C.; Leonardi, M.; Zaccone, R.; Fonda Umani, S.; et al. Microbial assemblages for environmental quality assessment: Knowledge, gaps and usefulness in the European Marine Strategy Framework Directive. Crit. Rev. Microbiol. 2016, 42, 883-904. [CrossRef]

40. Grifoll, M.; Jordà, G.; Borja, A.; Espino, M. A new risk assessment method for water quality degradation in harbour domains, using hydrodynamic models. Mar. Pollut. Bull. 2010, 60, 69-78. [CrossRef]

41. Grifoll, M.; Del Campo, A.; Espino, M.; Mader, J.; González, M.; Borja, A. Water renewal and risk assessment of water pollution in semi-enclosed domains: Application to Bilbao Harbour (Bay of Biscay). J. Mar. Syst. 2013, 109-110, S241-S251. [CrossRef] 